\title{
Parables of Pacific Shores: Locations, Caves and Coastal Masculinities in Cast Away and Sanctum
}

\author{
Allison Craven
}

James Cook University

\section{Locations and the transnational tropics}

I f one should imagine a map of production locations for dive films or films set on tropical islands since the 1960s, it would likely show a trend towards the southern hemisphere and more recently towards Queensland. ${ }^{1}$ Creative industries development in Queensland has been stimulated partly by state bodies, namely the Pacific Film and Television Commission, and Screen Queensland; and the presence of Warner Roadshow Studios on the Gold Coast, and filmmakers have also been attracted more recently by production offsets from Screen Australia. There is dim connection to the classical geography of the Antipodes as the underside of the world and a place of monsters.

Cast Away (Zemeckis 2000) is part of this presumed trend, and Sanctum (Grierson 2011) has direct connections to Queensland, and was supported by Screen Queensland. These films represent rather differing treatments of the tropics, but I link them first through their production histories in the Pacific region. Thereafter, in this article, I look closely at the role of coastal settings in these films, especially water, shore and cave, in correlating the spectacles of aquatic man and tropical mise-en-scene. I reflect on how the semiotics and performativities of white masculinities in quests for survival reference the cultural and industrial geographies of production locations and narrative places in the Pacific region. Cast Away, the tale of a Fedex logistics executive, who is fated to dwell on an isolated island following a plane crash is a touchstone island movie that was part-filmed on Monuriki Island, off the coast of Fiji, and fictionalised as "600 miles south of the Cook Islands” (Zemeckis 2000)2. Sanctum concerns a team of cave-divers in New Guinea who become trapped when a storm unexpectedly turns into a "cyclone" and floods the cave. The New Guinea setting resembles Alister Grierson's first feature film, Kokoda (2006). For Sanctum, dive locations were scouted in Vanuatu, Puerto Rico, Yucatan, Australia and Papua New Guinea (according to Andrew Wight in Grierson 2011a) before the decision to film in customised sets at the Warner Roadshow Studios. Second-unit footage of Mt Gambier and Narracoorte Caves, South Australia, and some exteriors of Dunk Island, North Queensland also were used (and imdb.com also mentions the Cave of the Swallows, Mexico as a location).

Both of these films therefore challenge us as Jane Mills (2009) suggests to consider the 'location' of Hollywood and to notice the outlands that compose it, and how audiences become implicated in these imaginings. For Cast Away, the production and fictional relationship to the South Pacific is essentially unacknowledged as a potential source of its meaning yet Monuriki has subsequently become one of Hollywood's outposts, a pilgrimage site for movie fans, tracing the place where Chuck

\footnotetext{
${ }^{1}$ Documentary film has a more extensive relationship to Pacific locations as Patty O'Brien (2006) points out, at least going back to Robert Flaherty's Moana: A Romance of the Golden Age, filmed in Samoa in 1926.

${ }^{2}$ See also “Cast Away: Production Notes” http://culture.com/articles/166/cast-away-production-notes.phtml
} 
Noland (Tom Hanks) was lost. ${ }^{3}$ (The television series, Lost ${ }^{4}$, which was devised independently as a serialized retelling of Cast Away, was shot in the United States mainland and Hawaii, and therefore can be seen as a further stage in Chuck's home-coming, if location is seen as more than a latent aspect of the medium.) The transient use of Dunk Island in Sanctum barely hints at the lengthy list of beach and aquatic settings produced in Queensland film and television ${ }^{5}$ which was once more associated with the surfing leisure of the Gold Coast but has more recently been oriented to the tropical north. Moreover, with Sanctum, as Michael Body (2011) reports, Grierson has "joined a select group of Australian directors to head a film earning \$US100 million (\$105.m) or more” (17). This success has been assisted by "opening in China . . . and performing well, taking \$US10m there in 10 days" at the time of Bodey's report. Bodey explains that Sanctum was apparently "one of only 20 international films allowed commercial release" in China in 2011. It is also said to have done well in Japan (in spite of the tsunami)--and Bodey notes the value of executive producer James Cameron's “imprimatur...in that market"--and in Brazil, South Korea and Russia. While identified as an Australian film, like any film today the production and reach of Sanctum is transnational. It is unclear as to whether the move to capture new audiences in China was at Grierson's or the producers' initiative, but it is a move in parallel with trends in the wider economy and, in the national context, is comparable to the predominant coal production industry in Queensland, which is said to now be largely harnessed to consumption by China. As an American-Australian co-production leveraged towards Asian and especially Chinese audiences, Sanctum represents a re-orientation of the transnational trajectories of Australian film.

I revisit these issues in the Conclusion to this article. First, I explore caves (forgive the pun) as the key sites of masculine identity in both films. Whereas audiences are likely to recall that Chuck, in Cast Away, is marooned on an island, it is more often overlooked that he dwells in a cave and this amnesia is, I argue, imposed through Chuck's own recollections of the island. While Chuck regresses to a cave man, in Sanctum the expert cave-diving team are entombed within a vast cave system--quite literally, a mundus subterraneous or underworld. These coastal adventure tales therefore literalise and extend the patterning of caves and underworlds drawn to attention by Victoria Nelson (2001) in tracing the persistence of the grotto or cave in representations from antiquity (notably Plato's parable of the cave) to postmodern culture. Caves, Nelson argues, allegorise immersion in the unconscious and, conversely, emergence from a cave implies surfacing to consciousness and recognition and transgression of the boundaries of world view. This pattern persists in these modern parables in Pacific aquatic settings, so that our heroes Chuck, Frank (Richard Roxburgh), Josh (Rhys Wakefield) and Plato together represent a continuum of caving masculinities. Where Chuck is ambivalent about the cave, in Sanctum, I argue that those iconic Australian masculinities, 'blokes' and 'mates', are adapted and supplemented with the classical mythology of caves and water, underwritten by the risks and masculine values of extreme sports. While these risk-masculinities somewhat disturb the colonial myths of the Pacific region, I suggest in the Conclusion that they stand for more contemporary concerns in the era of transnational film and industry.

\section{Robinson Caveman and Men at Work: Caves and Cavers}

Places of healing cults and wisdom in pre-Socratic Greek thought and a metaphor for perception in Plato's philosophy, caves are inherently associated with masculinity through an originating myth of human evolution in the figure of the 'cave man'. This myth persists notwithstanding the sibyls and caverns of classical mythology, and the many feminised spectacles of caves and grottoes as "pseudo-

\footnotetext{
${ }^{3}$ See for instance "Castaway Island" at http://famouswonders.com/castaway-island/ (2011); and "Monuriki Island Fiji" at http://www.wearetraveller.com/2010/10/monuriki-island-fiji-most-unusual.html (2010/2012).

${ }^{4}$ Various. Lost. ABC Studios/Touchstone Television. 2004-2010.

${ }^{5}$ See, for instance, Craven and Mann (2010).
} 
mystical places” in nineteenth century theatre (Monros Gaspar 2009). Irrespective of the classical and theatrical legacy, a cave is a distinctly ambiguous landform, a liminal form between terrestrial and marine environments, and potentially both shallow and cavernous. Chuck's cave is a modest inlet along the shore, an unthreatening space and typical of a 'grotto'. The heroes of Sanctum on the other hand traverse sub-marine caves within the coastal landscape. Plato's cave we are told is underground, a "cavernous cell" and "shadows" are cast by a fire onto the walls (Plato 60-61). But is the cave coastal or inland, marine or terrestrial? Chuck's plight may resemble those prisoners of Plato's cave but whatever knowledge he gains, after his rescue Chuck distances his debt to Plato.

Cast Away suggests the condition--cast away--of the subject rather than the 'castaway', the stock type of imperial adventure tales and 'Robinsonades' such as Treasure Island, The Coral Island and The Swiss Family Robinson, all set on islands in the South Pacific ocean. In Cast Away, the Robinsonade is enacted in the extended middle passage, which was also that of the location shoot on Monuriki. The plane crash provokes a juxtaposition of the metered, mobile world of corporate man with the timeless space of the uninhabited island, and the mythic extremities of suffering to which Chuck is subjected. Chuck's island life is at first characterised by his paunch and lack of mastery of the island habitat; and "Four Years Later" he is seen as a spear-wielding and physically fit figure styled as a noble savage. While the cave provides shelter from the tropical storms, Chuck's occupancy of it suggests his emblematic regression from company man to stone-age cave dweller.

The remaking of Chuck's identity and consciousness is strongly suggested as Chuck's--and the cinema audiences'--first encounter with the island is in darkness amid rocks, with Chuck unconscious following the crash. Chuck wakes on the beach with water in the foreground, sand and palm-trees behind him, so that land is subordinated to sea in the view of Chuck's landing place. While the adventure tradition and Robinson Crusoe myth instil the idea of islands as spaces in which "[b]oy heroes can act as the natural masters of these controllable environments” (Bristow 1991, 94), Chuck's island is not a joyous realm of adventure but a test, a struggle, and an extreme form of exile. On coming to his senses, Chuck first locates his beloved Kelly's watch. Then he collects salvage and is seen opening coconuts, spearing clumsily at fish, and timidly exploring and finding a cave that is approached through water. But Chuck does not occupy the cave until some time later. A sequence of scenes intervenes, with Chuck fashioning stone tools to break coconuts, making fire, and writing and hand painting on the cave walls, all strongly coding the hero's regression to a 'cave man'.

The shore and the cave sustain the perception of Chuck's island habitat. Climbing a cliff, he gains a vantage point from which he surveys the surrounding ocean. Later, after rescue, he speaks of how in his loneliness he wished to hang himself and was prevented by the lack of sturdiness in the only tree on the cliff, and the form of the surrounding land, and how this profoundly influenced his sense that he had "power over nothing", until the tide eventually delivered "a sail". Aside from this reflection, and his returning of the watch to Kelly, Chuck expresses no other recollections of his island life when reunited with his colleagues. He tells no hero's tale of his survival methods, and effectively disavows the cave-dweller. Instead, he re-avows his corporate values, expressing the conviction that a package saved his life, adding a moral and posting a parable of exile and return. Decorated by the sender with angel's wings, the said Fedex package--an item of one of the most visible incidences ever of product placement in cinema--has been much lampooned, most famously in a gag where the last scene is rewritten to reveal that the package contained a satellite phone ${ }^{6}$. Less obviously, a 'package' resonates with a corporate salary as befits a company man like Chuck, and it strengthens the association to Robinson Crusoe more readily than to that of Chuck as a cave man.

\footnotetext{
${ }^{6}$ Several sources claim this joke. See "Why no matches in the Fedex box?" http://money.cnn.com/2003/01/27/news/companies/superbowl fedex/index.htm (2003) where it is said to have been scripted for a Fedex advertisement; and "What was in the box with the angel wings?" an "FAQ" entry at http://www.imdb.com/title/tt0162222/faq\#.2.1.1 that attributes it to Zemeckis.
} 
If Chuck's cave is a grotto, Sanctum fields a team of divers in a cavernous region that inspires awe and power. The dive team is led by the hard man, Frank, who becomes trapped along with his son, Josh, his mate George (Dan Wyllie); Judes (Alison Cratchley) an expert woman diver; Victoria (Alice Parkinson), a mountain climber on her first dive; Carl (Ioan Gruffudd), her fiancé, a wealthy adventurer; and Luko, Frank’s loyal offsider. The group descend into the monster cave system, a perilous risk-filled world that demands deep surrender and forms of sacrifice. Sanctum, the title, also bestows the sacred aura of the deep cave. As the tensions and dangers escalate, their entrapment implies that the cave is nature, an awesome mother-monster whose inhabitants swim within it and are subject to its perilous passages and internal micro-climates abetted by exterior weather.

This sense of 'environment' figured by the deep cave system is pitted in relation to team masculinity in Sanctum, and the adventure of cave diving is knowingly expanded into the production discourse as most of the production team are (or were) cave divers (Grierson 2011a). James Cameron says Sanctum offered audiences a "unique and exotic environment" that "most people have never seen" (Grierson 2011a); and as it was shot in 3D the cave environment is hyper-realised. The actors speak of the challenges of learning to dive, abseil and rock-climb for their parts, and they and Grierson comment on the "physical" challenges of making the film (Grierson 2011a). Produced and written by cave divers, John Garvin and the (now late) Andrew Wight, Sanctum is also dedicated to the late Wes Skiles, the "world's leading underwater cave cinematographer" who, along with Wight, was involved in an actual cave collapse in 1988 when 15 people were trapped in a cave on the Pannikin Plains on the Nullabor (Grierson 2011a). Documented in Nullabor Dreaming (Larkin 1989) the incident resulted from a freak storm of cyclonic power which dropped two years' worth of water in 25 minutes, flooding and collapsing the cave. The rescue of the cavers took nearly two days, although there were no fatalities (Grierson 2011a). These events are obliquely referred to in Sanctum.

The fictional expedition of Sanctum, however, is primed with allusion to caving as exploration, and the contest with nature invited by cave diving. Carl speaks of the "last primeval wilderness", and the cave as the entry to earth's crust; "the beginning of time", in Frank's words. The plot concerns the risks of exploration of these uncharted reaches of the cave system, and couches a theme of masculine identity: "Why do we cave, Josh?" asks Carl, and later reflects "to shine a light where no one's been before”. Josh is more cynical about cavers due to his father's obsessions. But Carl says Frank is the "most respected explorer of our time" like a "Columbus or a Neal Armstrong" and that apart from "these caves, there’s nowhere else left on the planet to explore" (Grierson 2011). Momentarily and silently edited into these sequences is a Papuan medicine man with a bone through his nose, perhaps forewarning of the menace of the brewing storm ("cyclone") "right off the coast" (says Jim played by John Garvin), and the primeval depths of this cave system. A complex communication regime is deployed to monitor the cave environs but Frank is sceptical of what the computers can reveal because "a machine can't feel the cave, George," he insists. Nevertheless, the Sanctum team converge, base-jumping and abseiling to the dive platforms within the cave, and trusting to the phalanx of technology--lamps, laptops, depth sensing equipment and remote cameras. The highest tech add-ons that money and science can muster, the dive team's efforts are ultimately futile as the deadly peril of the cave is provoked by an exterior weather system, the storm. It is a risk factor that, while detectable, seems unpredictable, and notwithstanding the ominous presence of the bone-man and his ancient wisdom.

Thus the coastal cave setting contrives that most noted feature of modern masculinity, the taste for risk, a desire supplemented with--or abetted by the lack of--technology in both films. In Cast Away, Chuck is not an active adventure seeker; his quest for survival in the tropics results from a work accident, and his acquired taste for risk in trying to escape the island is constrained by his crude resources. Sanctum, on the other hand, is the very dramatisation of risk-taking. Frank and George are dedicated cavers, and according to Carl, Frank is the "most determined cave diver in the world" but in Josh's view this is because "he's got nothing else". We never learn the nature of their paid work-although in backstory, Carl is said to be a "CEO of his own company" (Grierson 2011a)--and Carl has funded the equipment for the expedition. The drama of their risks taken at the mercy of Pacific 
weather and the cave environment, are mediated, as I suggest below, by the conventions of mateship and the gender codes of extreme sports. Their protracted fate permits them time to reflect upon the manner in which they face death because, in the tropics, aquatic man--if not born--is more likely to die in water, a fate that Chuck the castaway narrowly avoids.

\section{Pacific masculinities at risk: Bodies, water, Oedipus rising}

"George was right. I never knew my father. I found him in that cave. He was a helluva fella, once you got to know him.” (Grierson 2011)

These are Josh's words, echoing a sentiment expressed earlier by George, heard in voiceover through a high shot of Josh struggling to shore after his escape from the cave, in the concluding scenes of Sanctum. Josh's survival bespeaks not only his coming of age and the wisdom of the cave/r, but also myths of gender in the Pacific.

Analysis of gender in Pacific settings is mostly of femininity, and water, Patty O'Brien (2006) points out, is feminised in classical mythology. Pacific exoticism, she argues, can therefore be traced to classical types, namely "Odyssean temptresses" (9) - the likes of Circe, Calypso and the sirens - as a "central theme of the Odyssean myth, which became core to Occidental colonization, is the travelling man's exposure to sexual danger" (41). The classical associations of water and ocean with the goddess Aphrodite (or Venus in Roman tradition) (see 47-49), and the influence of legends of sirens and nymphs on portrayals of Pacific women, lead O'Brien to suggest that not only the sexuality of woman but also her "environs determined her erotic potential" (51). The heightened libido said to be brought on by hot weather, and the state of undress of native women in the Pacific was also associated with sexual readiness (79). While the "unfettered sexual freedom of voyaging men" was a key myth of the South Seas (68), their inability "to withstand temptation was the great paradox within constructions of . . . civilized, Occidental masculinity” and O’Brien suggests that this was partly justified as the effect of the greater seductive power of South Seas women compared to those at home (75).

In departure from this myth, the travelling men of Cast Away and Sanctum are locked in chastity, either travelling in couples with women from home (Carl and Victoria), or yearning for reunion (Chuck for Kelly), or attached in male bonds of mateship (Frank and George), or loyalty (Luko), or engaged in Oedipal hostilities (Frank and Josh). Sexual action is wholly sidelined from Sanctum as it is in Cast Away where Chuck's island celibacy is unquestioned as loyalty to Kelly. Aquatic man's quasi-nakedness is seen as induced by the coastal-marine settings, allegorising their (natural) equipment for the environment rather than sexual readiness. Male quasi-nudity also descends in island settings from the naked lads of The Coral Island (Ballantyne 1994/1857); and The Blue Lagoon (Henry De Vere Stacpoole 1908) where, according to Joseph Kestner (2010) male maturation is presented as a process of "de-civilising” signalled by "wandering around naked" (158-59). Chuck in his island habitat strips and becomes a version of the noble savage, while the stricken cavers in Sanctum are clothed skin-tight in their diving gear, their quasi-nakedness com-modified by the Neptune brand placement, and their skirmishes over torches and supplies impeded by water and wave. (Richard Roxburgh seemed so much more at home in $R_{a k e}{ }^{7}$.) Their bodies are all but bare, but their emotions and desires are regulated by team mateship and are congruent with the masculine values of extreme sports.

The adventure of caving as it is performed in Sanctum involves multiple extreme sports aside from cave-diving, including rock-climbing, free-diving and more. Forms of extreme sport offer "empowerment” through "demonstrations of skill and strength" according to Victoria Robinson (2008, 43), who refers to a range of such sports, especially rock-climbing, in her research. While

\footnotetext{
${ }^{7}$ Various. Rake. Essential Media and Entertainment/Blow by Blow Productions/Screen Australia/ABC. 2010.
} 
extreme sports are seen as individualised and non-competitive compared to commercial team sports, Robinson identifies how participants' perceptions of hierarchies of extreme sports are sometimes based on the risks to mortality that boost how "exciting, or dangerous or special" they seem (46). Spatiality and environment are important to some participants, such as a rock climber who relished that it's “"about environment as well....wild, wild places”' (qtd in Robinson 46). For rock climbers, she found that the choice of environment - whether authentic or in the relative safety of a climbing wall - contributes to a "more or less masculine" self-image or the sense that a "particular kind of climber" is seen as a "particular type of man" (49). More generally, risk is sometimes seen to add authenticity and hence affect the more or less masculine self image; so, to adapt, a particular kind of risk-taker is seen as a particular type of man. Even so, Robinson points out that research on risk yields complex findings, ranging from a "courting" of a " "terrible sublime'” of death to the minimisation of risk in order to "climb another day" (148) (while research comparing safetyconscious work environments and high risk sports revealed some tendency to maximise risk in the sport).

In Sanctum the experienced divers are highly conscious of risk and their emotional energies are directed towards both the risk and the potential wonder of the cave. But they are foiled by the sheer danger of the cave environment, and the surprise element of the external weather change. So the safety-consciousness of the team is neutralised in the drama, and peril gains the suspense advantage. It also generates the emotive sub-narrative of the tensions between Frank and Josh, in which Luko and Frank are implicated as mediators. Frank assures Josh that his father is a "helluva fella...once you get to know him". Emotion seeps out of Frank in poetic ways as he is fond of reciting S.T. Coleridge “"In Xanadu did Kubla Khan / a stately pleasure dome decree: / Where Alph, the sacred river, ran, /Through caverns measureless to man / Down to a sunless sea" - a gesture both sentimental and nostalgic as he discloses, in teaching it to Josh, that Josh's mother liked the poem. The 'sacred river' also signifies Frank's quasi-mystical wisdom in following the river out of the cave, and more mythically instils the maternal aura of the cave. The extreme sport of cave-diving therefore adapts a notion of sport as a legitimised arena for men's emotion, and as the intense level of risk mounts unavoidably it is shown to propel these emotional bonds. But all is in vain as one by one death takes its toll on the dive team.

The first to perish is Judes, who becomes wedged, damaging her breathing equipment and drowning, and thus the post-feminist equality of the dive-team is savaged by the cave. Luko is severely injured when swamped by a surge of water only to be despatched with mercy by Frank. George 'fizzes up' with decompression sickness; Victoria perishes when she defies Frank's warning not to use her knife to cut free her hair when it becomes entangled in the rock-climbing rig and scalping her. But whereas Judes and Victoria fall victim to the shortcomings of equipment and individual competencies, the deaths of the male team members measure the limits of their bodies' capacities to withstand the environment of the cave. Frank is finally felled when fatally attacked by an hysterical Carl, who is deranged by the death of Victoria and later drowns in despair.

The deaths seem to travesty any 'terrible sublime' of high-risk adventure, and Frank is provoked to observe that “there's no god down here...this place doesn't give a rat's arse about ...us...we're bits of dust passing through”. But, in spite of this anti-theology a certain cave spirituality surrounds Frank's own exit as it is prefaced by his reflections on himself as a caver, and accompanied by reconciliation with Josh. In the moments before Carl attacks him, Frank confesses to Josh, “I know I haven’t been anything of a father to you...I'm not much good up there full stop...cities, cars and mortgages...down here I can make sense of this...it's like my church. I can hold a mirror up and say this is who I am." Fatally injured, Frank begs his son to mercy kill him, and urges him to "trust the cave, trust the cave, follow the river, it'll lead you out”. Frank's sacrifice and Josh's survival thus imbue the virtue of risk and masculine self-image in extreme sports - the wisdom that a particular kind of caver is a particular kind of man. 
Obeying his father, Josh takes the last rebreather and swims to safety, aroused from the unconsciousness of near drowning and finding an outlet into the ocean and swimming to shore. His emergence seems a rendering of parturition as he surfs down a canal-like opening, re-born to understanding of his father, in a parable of survival and getting of wisdom. Josh'a watery re-birth does not trouble the classical mythology of water and femininity, any more than that of the cave. Where Chuck revokes his debt to the cave, and avows and re-embraces the system that cast him away, the Sanctum team surrender to the cave, all of them submitting in death except for Josh, who nevertheless surrenders to Frank's spiritualised view of cave-diving as source of identity and the cave as a channel of knowledge and consciousness.

\section{Conclusion: The Slow Boat to China}

The international film industry is submerged in these accounts but gains profile in the story of the success of Sanctum. Its reception in China prompts reflection on how this film--and perhaps more to come--represents a coalescence of the interests of the creative and primary economies of the nation. While mining is not caving, the endeavour of exploration is common in both practises, and technologised exploration of an inner-earth underworld bears symbolic if not literal comparison. This is not to mention the male-dominated associations of team enterprise and the health, safety and environmental risks that are known to proceed. That an economic metaphor--let alone a mining metaphor--lurks in the cave depths of Sanctum or Cast Away is only far-fetched if the investment of such films in reprising and extending the ideology of team masculinity and mateship and its potential costs are not overlooked in any national enterprise; or, if Chuck's trust in his package is seen as innocent. Frank's sacrifice and Chuck's salvage and the films of their stories attest that any kind of man--caver, miner, logistics executive, filmmaker or producer--owes their identity and relative power as much to the location and conditions of their environment as to any myth of masculinity, and that, without due care, these elements are potentially as fluid in reality as they are in the cinemas of the transnational tropics.

\section{Works Cited}

Ballantyne, R.M. The Coral Island. Puffin 1994 (first published 1857).

Bodey, Michael. "Sanctum scores a century at the box office." The Australian 'Film Arts', 5 Oct, 2011, p.17.

Bristow, Joseph. "Island Stories.” Chapter 3 in Empire Boys: Adventures in a Man’s World. London: HarperCollinsAcademic, 1991. 93-126.

Craven, Allison and Mann, Chris. "The Girl with the Bush Knife: Women, Adventure and the Tropics in Age of Consent and Nim's Island.” Refereed Proceedings of the Inaugural Tropics of the Imagination Conference, 2-3 November 2009. etropic: electronic journal of studies in the tropics, Vol 9 (2010), <http://www.jcu.edu.au/etropic>

Grierson, Alister. Kokoda. AFFC / GFN Productions / Pacific Film and Television Commission. 2006.

----. Sanctum. Great Wight Productions / Osford Films. 2011.

---. Sanctum: The Real Story. Great Wight Productions / National Geographic Channels. 2011a. 
Kestner, Joseph A. Masculinities in British Adventure Fiction, 1880-1915. [electronic resource] Burlington VT: Ashgate, 2010.

Larkin, John. Nullabor Dreaming. Great Wight Productions/Osford Films. 1989.

Monros Gaspar, Laura. Classical Myths on the Victorian Popular Stage: The Figure of Cassandra. Doctoral Dissertation. Valencia, Spain: Universitat de Valencia, 2009.

Mills, Jane. Loving and Hating Hollywood: Reframing global and local cinemas. Crows Nest: Allen \& Unwin, 2009.

Nelson, Victoria. The Secret Life of Puppets. Cambridge, MA and London: Harvard UP, 2001.

O’Brien, Patty. The Pacific Muse: Exotic Femininity and the Colonial Pacific Seattle and London: U of Washington Press, 2006.

Plato. From Republic: Book VII. Trans. Robin Waterfield. The Norton Anthology of Theory and Criticism. $2^{\text {nd }}$ edn. Vincent B. Leitch (ed). New York and London: Norton 2010. 60-64.

Robinson, Victoria. Everyday Masculinities and Extreme Sport. [electronic resource]. Oxford and New York: Berg, 2008.

Zemeckis, Robert. Cast Away. Dreamworks and Twentieth Century Fox. 2000. 